\title{
The Role of Energy Accumulation Systems in Ensuring Energy Security of the State
}

\author{
V.V.Velikorossov" ${ }^{1, *}$, E.V.Genkin ${ }^{1}$, A.K.Zakharov ${ }^{1}$, M.I.Maksimov ${ }^{1}$, S.A.Filin ${ }^{1}$, \\ A.K.Khudaibergenov ${ }^{2}$ \\ ${ }^{1}$ Department of Organizational and Administrative Innovations, Plekhanov Russian University of Economics, \\ Moscow, Russia \\ ${ }^{2}$ L.L.C. «Husnutdin Saliev», Nukus, Uzbekistan \\ *Corresponding author
}

Keywords: Innovations, Energy Transformation, Industry 4.0, Energy Storage Systems, Resop, New World Power System Architecture, Energy Security, Environmental Requests

Abstract: Further growth of the Russian economy is impossible without solving a number of tasks that are a consequence of the challenges that technological progress poses to virtually every developed country. The presented article tells about such an important element of the country's energy network as energy storage systems (ESS). The role of this element is viewed through the prism of current problems the Russian power industry is facing.

\section{Introduction}

The key factors of energy transformation are:

- $\quad$ changes in external factors, including the need to ensure the energy security of the state;

- the increase in environmental requirements;

- the formation of a new technological structure and the new structure of the country's energy system.

These changes pose other tasks in terms of overcoming the following challenges:

1) Ensuring energy security. The term "energy security" means a set of tools aimed at ensuring the protection of ultimate consumers of energy resources from risks caused by various factors, including natural disasters, terrorism, and the lack of sufficient and timely financing of infrastructure projects in the energy sector [1]. Taking into account the multiple growth in the use of carbohydrates, guaranteed energy supply is one of the key factors for the stable economic development of society and the state. At the same time, the key initiatives of the challenges are providing of the uninterrupted reliable fuel and energy supply, reducing the probability of emergency situations, ensuring the required volume of output at renewable sources of power (hereinafter also referred to as RESOP) [2].

2) Industry 4.0. Since the beginning of 2000-x years the world has witnessed a "new industrial revolution" or "industry 4.0", which has formed a pool of challenges associated with technological changes in the global economy. This process gave impetus to the creation and development of universal (digital) platforms that aggregate large amounts of data and algorithms of its processing. 
Key countries are implementing large-scale state programs in the field of advanced technologies in various economic activities. In particular, in the United States adopted the "Strategy of Innovation Development" [3], the "National Strategic Plan for the Development of Advanced Industrial Technologies of the United States" [4] in Germany was initiated by the industrial strategy "Industry 4.0" as one of ten "Future Projects" under the "Plan for the Implementation of the Updated Federal Policy in the Sphere of High Technologies" [5]. In turn, France launched the program "New Industrial France" [6], including the projects of the future technological development. Japan runs the 5th five-year development plan of science, technology and innovation (2016-2020). China is implementing the program "Made in China 2025" and "Internet+" [7] since 2015.

3) The new structure of the World Energy System. Most of the world is in the process of a radical restructuring of its energy system. The most important incentives that determine the format and direction of this dynamic are the depletion of cheap carbohydrates and the increase in its cost, the development of renewable energy sources, made possible by reducing the specific cost of technology. In turn, they stimulate trends associated with the decentralization of generation, the emergence of the category of prosumers, and the growth of the quality of electricity $[8,13]$. An additional trend is urbanization and the formation of new urban agglomerations, the growth in the number of electricity consumers against the background of population growth, "energy commodification" - creating a stock for sale and transportation, using energy storage systems (hereinafter also referred to as ESS).

4) Environmental request. Improving the environmentally friendly industry means interacting with such challenges as reducing greenhouse gas emissions, implementing projects for active energy conservation, developing electric vehicles and related infrastructure, improving the energy efficiency of traditional industries and developing innovative technologies, developing alternative energy sources, including RESOP, hydrogen fuel and introducing and developing systems of power storage technologies [9].

\section{Materials and Methods}

As can be seen from the challenges, discussed above, the development of ESS is one of the factors that makes it possible to remove limitations have been mentioned, especially with the integrated use of intelligent control systems and digital networks.

Electric power storages are a fundamentally new element of the energy architecture that organically supplements generation, transmission and consumption facilities and opens up broad opportunities. Among them:

- the effective realization of the potential of new types of distributed generation;

- the creation of active consumers;

- the increase in the efficiency of the use of capacities that are already put into service as well as the new energy capacities;

- the boost of the efficiency of the operation of energy systems in general;

- ability to introduce completely new architectures [7].

The key advantages of using energy storage devices were structured in the context of the challenges facing the energy industry, taking into account the diversity, features and capabilities of existing and future energy storage technologies, as well as their individual characteristics (presented in Table 1). 
Table 1. Capabilities of Energy Storage Systems in Ensuring the Energy Security of the State

\begin{tabular}{|c|c|c|c|c|c|}
\hline$\#$ & Advantages of ESS Challenges & Energy securit & $\begin{array}{c}\text { Industry } \\
4.0\end{array}$ & $\begin{array}{l}\text { New world } \\
\text { power } \\
\text { system } \\
\text { architecture }\end{array}$ & $\begin{array}{l}\text { Environmen } \\
\text { tal requests }\end{array}$ \\
\hline 1. & $\begin{array}{l}\text { Consumption optimization (peak } \\
\text { consumption shift) }\end{array}$ & + & + & + & + \\
\hline 2. & System reliability ensuring & + & + & + & + \\
\hline 3. & $\begin{array}{l}\text { The emergence of an additive } \\
\text { digital services market }\end{array}$ & & + & + & + \\
\hline 4. & Emergency generation & + & & + & \\
\hline 5. & Black start & + & & + & + \\
\hline 6. & Transmission support & + & & & \\
\hline 7. & Integration of RESOP generation & + & + & + & + \\
\hline 8. & Ultimate consumers' benefits & & + & + & \\
\hline 9. & System reliability & + & & & + \\
\hline 10. & Thermal power storage & + & & + & + \\
\hline 11. & $\begin{array}{l}\text { The development of private } \\
\text { electric transport }\end{array}$ & & + & + & + \\
\hline
\end{tabular}

\section{Results and Discussion}

\subsection{Consumption Optimization}

Shift of peaks of electricity consumption when using ESS allows accumulating energy during off-peak time and supplying energy during peak demand, which creates a synergistic effect due to the difference in the cost of energy multiplied by the sales volume. Optimization of consumption is possible both in the intraday interval, and in the framework of longer-term periods (monthly, seasonal peaks) when using larger capacity drives.

Reducing peak consumption is an exceptional benefit for the entire power grid. It allows to increase the lifetime of existing generating assets by increasing its load during peak hours, which also increases the amount of energy sold while the stations operate with higher efficiency. On the other hand, reducing the peak consumption value reduces the need to create additional generation, which leads to a significant decrease in the volume of investments in new generating projects.

Also shifting consumption peaks leads to lower costs in the electricity and power market. Consumers often pay for electricity based on maximum power consumption, based on a 15-30 minute consumption period per month. Using storages of even small capacity, large consumers will be able to significantly reduce their peak monthly consumption and thereby reduce total payments.

Shift of peak consumption is the most significant and massive effect from the use of existing energy storage systems, $98.5 \%$ of the world's pumped storage power plants (PSPP) are intended for these purposes. The current trend for the development of renewable energy generation and, in particular, wind generation is the key basis for the development of other energy storage technologies, including in the part of electrochemical storage devices.

\subsection{System Reliability Ensuring}

Payment of peak power is carried out to stimulate investment in the construction of new generation and pumped storage plants by providing guaranteed incomes. They stimulate electricity producers to build a sufficient amount of new generation to meet the peak load and receive adequate 
payment for it [10]. Annual payments for capacity should be based on the type of generation and generation capacity. Additional advantages of using energy storage compared to traditional generation are the ability to control the time of consumption and distribution of electricity. This creates a double advantage - receiving payment for the peak power and effect of the arbitration of electrical energy.

\subsection{The Emergence of an Additive Digital Services Market}

Additive services are a complex of digital services necessary to maintain the security, reliability and stability of the electrical network. Additive services maintain the balance of supply and demand, the voltage levels in the network, and also hold the available power reserve for distribution to the network during an unexpected increase in load, which can destabilize the power system.

\subsection{Emergency Generation}

Emergency generation is the power reserve used during emergency blackouts in the network. Electric power stations providing emergency generation services are able to quickly join the network and increase production in less than 10-15 minutes.

\subsection{Black Start}

Is used to restart generators during a power blackout, which requires a significant amount of energy. For example, steam turbines require up to $10 \%$ of their power to restart after an idle time. Generators capable of providing cold start allow you to reach full capacity without reliance on external forces. For example, some hydropower plants (HPPs) have batteries and diesel generators to resume work after a malfunction. These hydropower plants are further used to restore power supply at neighboring power plants and gradually restore the system. Large-scale ESSs, such as PSPPs and metal-air, are able to provide this service.

\subsection{Transmission Support}

Energy storage to support transmission improves carrying capacitance and reduces transmission losses, and also avoids unstable voltage levels and harmonics. The usual discharge time for this service is from 1 to 20 seconds. ESSs perfectly meet the requirements, as they has a very fast response time and are capable of using reactive power, and also very reliable in use.

\subsection{Integration of RESOP Generation}

The RESOP generation in the power system covers a number of opportunities for using ESS, which differ significantly on the basis of technical requirements. For large-scale wind and solar farms, there are several options for using energy accumulators: to smooth out short-term fluctuations, to protect against a rapid increase or decrease in output power. These systems can also be used to maintain a stable voltage level. Long-term storage systems can facilitate large-scale integration of renewable energy sources in several areas at once. ESS can improve efficiency, reduce volatility and provide a hedging process for the forecast of renewable energy. ESSs also provide the ability to shift production peak to off-peak demand. They can also be used to reduce the cost of building network infrastructure as a backup capacity, by increasing the efficiency and reliability of existing equipment of renewable energy sources. Greater economic effect is achieved when ESS is located directly on the renewable energy facility and is integrated into the production cycle.

ESS can be used to avoid reducing the amount of wind energy when the electrical system is not able to absorb the generated electrical energy. Such situations can occur when the network has insufficient capacity or because of the impossibility of dispatching and the inclusion of volumes of energy due to excessive generation or high fluctuations. In turn, the types and varieties of ESS are 
selected taking into account the features of each project. The generated energy of local generators of renewable energy sources can be accumulated and used when and where it is needed. Based on this approach, the system regulator may receive additional benefits from subsidies due to a larger coverage area, and ultimate consumers can reduce their dependence on centralized energy supply.

\subsection{Ultimate Consumers' Benefits}

The use of ESS on the side of ultimate consumers to ensure an optimized schedule of energy consumption, as a result, will lead to a decrease in households' electricity and heat payments.

\subsection{System Reliability (Avoid Failures, Avoid Fluctuations in the Network).}

ESSs are used to provide guaranteed power supply during blackouts and scheduled/routine outages. The economic losses associated with these outages are an assessment of the effectiveness of ensuring system reliability [11], and this effect may differ significantly from the type of consumers: commercial, industrial or individual. As an alternative to using ESS as a backup, small diesel and combined-cycle power plants are currently used. Multi-hour emergency ESSs additionally contribute to the creation of local virtual power plants that are able to automatically balance supply and demand.

ESS can be used to prevent short-term fluctuations of the current in the network. Emerging critical load associated with fluctuations in the network, can negatively affect the functioning of medical equipment, high-tech production lines and data centers. Power fluctuations and interruptions can have significant operational and financial consequences. Avoiding these losses justifies investments in uninterruptible power supply systems that combine stabilization and energy storage systems of short duration.

\subsection{Thermal Power Storage}

District heating systems operating on solar, thermal, photovoltaic or geothermal energy are equipped with seasonal underground storage facilities to transfer energy from summer to winter, when necessary. Energy accumulation can optimize the efficiency of thermal power production, provide demand management. High-temperature storage of thermal power is used to improve the energy efficiency of power plants, as well as to prevent the empty release of thermal energy during cogeneration. Also, this application of ESS actively contributes to the reduction of $\mathrm{CO}_{2}$ emissions.

\subsection{The Development of Private Electric Transport}

The development of auto transport, the technological basis of which is usually made up of lithium-ion batteries, is one of the most popular ways of developing ESS. In turn, owning an electric vehicle automatically starts a related process to integrate former ordinary customers into the energy market, where they become users. This effect contributes to the development of distributed generation, smart networks and virtual power plants.

According to a study conducted in the UK, 10 million electric vehicles can increase the peak load by $3 \mathrm{GW}$ without using smart charging technology, and using advanced charging and demand management technologies, about 15 million electric vehicles will ensure the work of the UK power system as a whole [12].

Taking into account the global nature of the development of energy storage and energy storage technologies as a category, as well as the substantial ramification of the technological map and its variability of application, the key priority of the state energy security policy should be maximum integration into the structure of world $\mathrm{R} \& \mathrm{D}$ and production consortia with subsequent accumulation of competencies, knowledge and technology, or incorporation into process chains, which will increase the efficiency of development and reproduction and advanced technology. In Russia, the development of energy storage and accumulation technologies is constrained by a 
number of factors, the result of which ESS have not yet taken a stable position in the electricity and capacity market. The unique advantages of ESS, which can ensure the exclusive application of these systems in practice, still do not adequately ensure their cost-effectiveness.

\section{Conclusion}

Thus, taking into account the starting position for the development of the storage market in Russia and its role in ensuring the energy security of the state, it is advisable to take consistent steps in the following main areas:

- Elimination of barriers and stimulation of the creation of demonstration projects on the most promising, competitive technologies of ESS and conducting research and development on promising technologies;

- Providing support to ESS projects in order to implement them and integrate them into the power grid and achieve economic attractiveness for investors and owners.

\section{References}

[1].Baitov A.V., Velikorossov V.V., Karyakin A.M. Energeticheskaya bezopasnost' Rossii v usloviyah rynochnyh otnoshenij v elektroenergetike.- M.: Knizhnyj mir, 2012. - $224 \mathrm{~s}$.

[2].Levchenko D.K., Kalimullin L.V., Zubakin V.A., Tuzikova E.S., Smirnova YU.B. Analiz global'nyh i regional'nyh trendov, vyzovov $\mathrm{i}$ ih vliyaniya na perspektivy razvitiya sistem nakopleniya energii $\mathrm{v}$ Rossii v srednesrochnoj i dolgosrochnoj perspektive // Truboprovodnyj transport: teoriya i praktika. 2018. № 4 (68) S.61-67.

[3].Strategy for American Innovation // US National Economic Council, US Office of Science and Technology Policy. 2015.

[4].A National Strategic Plan for Advanced Manufacturing. Executive Office of the President, US National Science and Technology Council. 2012. URL: https://www.energy.gov/sites/prod/files/2013/11/f4/nstc_feb2012.pdf.

[5].The New High-Tech Strategy. Innovations for Germany. Federal Ministry of Education and Research of Germany. 2014. URL: https://www.bmbf.de/en/index.html.

[6].La Nouvelle France Industrielle. Ministère de l'Economie et des Finances. 2015. URL: https:/www.economie.gouv.fr/files/files/PDF/nouvelle-france-industrielle-sept-2014.pdf.

[7].Ekspertno-analiticheskij doklad «Novoj tekhnologicheskoj revolyucii: vyzovy i vozmozhnosti dlya Rossii». CSR. 2017. URL: https://www.csr.ru/issledovaniya/vozmozhen-li-v-rossii-tehnologicheskijryvok/.

[8].Velikorossov V.V., Karyakin A.M., Ryasin V.I. Ugrozy energeticheskoj bezopasnosti strany i regiona v usloviyah reformirovaniya elektroenergetiki // Trudy Instituta problem estestvennyh monopolij «Estestvennye monopolii $\mathrm{v}$ toplivno-energeticheskom komplekse Rossii». Vyp.2. - Moskva: IPEM, 2007. - S.62-80.

[9].Ekspertno-analiticheskij doklad «Rynok sistem nakopleniya elektroenergii v Rossii: potencial razvitiya». CSR. 2018. URL: https://www.csr.ru/issledovaniya/rossijskij-rynok-nakopitelejelektroenergii-mozhet-vyrasti-do-3-mlrd-dollarov-v-god. 
[10]. Velikorossov V.V., Karyakin A.M., Ryasin V.I. Organizacionno-ekonomicheskij mekhanizm obespecheniya energeticheskoj bezopasnosti regiona // Mezhvuz.sb.nauchn.tr. «Analiz sostoyaniya i razvitiya ekonomiki Rossii». Vyp.4. - Ivanovo: Ivan. gos. energ. un-t. - Ivanovo, 2007. - S.136-160.

[11].Velikorossov V.V., Kolibaba V.I., Ovsyannikov A.A. Analiz nadezhnosti funkcionirovaniya raspredelitel'nyh setevyh kompanij, vhodyashchih v MRSK "Centra i Privolzh'ya" za 2011-2016 gody // Razvitie integracionnyh processov v ekonomike Rossii-M.: Rusajns, 2018.- S.82-102

[12].The e-mobility revolution: impact of electric vehicles on the GB power system and emerging utility business models. Aurora Energy Research. 2018. URL: https://www.auroraer.com/wpcontent/uploads/2018/01/The-e-mobility-revolution-impact-of-electric-vehicles-on-the-GB-powersystem-Tuesday-23-January-2018.pdf.

[13].Khachaturyan M.V., Klicheva E.V., Velikorossov V.V. (2019) Digital Mechanisms of Development of Possessory Risk Management Systems under New Economic Conditions. Proceedings of the 2019 International Conference on Politics, Economics and Management (ICPEM 2019). Lecture Notes in Economics, Management, and Social Sciences. Clausius Scientific Press, Vol. 5. P. 6-10. 